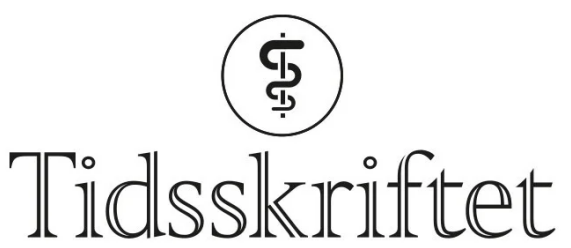

DEN NORSKE LEGEFORENING

\title{
Vi foreslår «anfallsforebyggende epilepsimedisin»
}

KOMMENTAR

\section{SVERRE MYREN-SVELSTAD}

s@myren-svelstad.no

Sverre Myren-Svelstad er lege ved St. Olavs hospital og stipendiat ved Norges teknisknaturvitenskapelige universitet.

\section{ROAR FJAER}

Ingen av forfatterne har oppgitt noen interessekonflikter.

Våre kolleger Nakken og Sætre tar opp en viktig diskusjon om presis begrepsbruk i epileptologien. De viser til at termen "antiseizure medicine» (ASM) i økende grad erstatter «antiepileptic drug» (AED) i engelskspråklig terminologi. De foreslår «anfallsforebyggende legemiddel» som norsk oversettelse (1). Vi syns dette begrepet blir litt upresist, siden det ikke sier noe om hvilken type anfall som forebygges. Vi foreslår i stedet «anfallsforebyggende epilepsimedisin» som norsk betegnelse.

Nakken og Sætre mener at innholdet $i$ begrepet «anfall» vil forstås $i$ «en artikkel om epilepsi» ut fra konteksten, altså at legemiddelet forebygger epileptiske og ikke eksempelvis migrenøse anfall. I den kliniske hverdagen vil det imidlertid kunne oppstå forvirring. På engelsk snakker vi om et epileptisk «seizure», mens det heter et migrenøst «attack». På norsk omtales begge deler som anfall. Vi kjenner heller ikke til at «seizure» på engelsk blir brukt om annet enn epileptiske anfall, slik at begrepet «antiseizure medicine» viser tydelig tilbake til sykdomstilstanden. Det vi i dag omtaler som «antiepileptika», brukes dessuten som behandling både mot epilepsi og migrene; enkelte pasienter har sågar begge tilstandene. Vi mener at det er viktig at man kan bruke de samme begrepene i forskning og klinisk virksomhet, og at begrepene bør være minst mulig avhengig av kontekst.

De tradisjonelle «antiepileptika» er riktignok ikke faktisk antiepileptogene legemidler. Fins det så nyere legemidler som er sykdomsmodifiserende epilepsimedisiner? Kanskje er dette tilfellet for enkelte sjeldne tilstander, som behandling med mTOR-hemmeren everolimus ved tuberøs sklerose ( $(\underline{2})$. Skal så denne legemiddelgruppen omtales som «antiepileptika»?

Etter vårt skjønn kan nye betegnelser for symptomatisk og sykdomsmodifiserende behandling ved epilepsi, til en stor del sidestilles med begrepsbruken ved multippel sklerose. Her brukes gjerne betegnelsen «sykdomsmodifiserende» (eller 
«immunmodulerende») MS-medisiner (3). Vi foreslår på samme måte at «anfallsforebyggende epilepsimedisiner» avløser «antiepileptika». Det andre leddet, «epilepsimedisin», mener vi vil forstås likefram som en medisin som brukes ved epilepsi, og at det ikke viser til virkningsmekanismen. På samme tid bereder man grunnen for god terminologi ved en framtidig revolusjon innen epilepsibehandlingen. Betegnelsen "sykdomsmodifiserende epilepsimedisiner» kan bli begrepet som omtaler de faktisk antiepileptogene legemidlene.

\section{LITTERATUR}

1. Nakken KO, Sætre E. Anfallsforebyggende legemidler, ikke antiepileptika. Tidsskr Nor Legeforen 2020; 140. doi: 10.4045/tidsskr.20.0536. [CrossRef]

2. Jozwiak S, Kotulska K, Wong M et al. Modifying genetic epilepsies - Results from studies on tuberous sclerosis complex. Neuropharmacology 2020; 166: 107908. [PubMed][CrossRef]

3. nevroNEL. nevro.legehandboka.no. Lest 9.9.2020.

Publisert: 12. oktober 2020. Tidsskr Nor Legeforen. DOI: 10.4045/tidsskr.20.0746

(C) Tidsskrift for Den norske legeforening 2023. Lastet ned fra tidsskriftet.no 26. april 2023. 